\title{
Clinical and In Vitro Evaluation of Cefazolin, a New Cephalosporin Antibiotic
}

\author{
KRISTEN RIES, MATTHEW E. LEVISON, AND DONALD KAYE \\ Deparlment of Medicine, Division of Infectious Diseases, Medical College of Pennsylvania 19129, and \\ Veterans Administration Hospital, Philadelphia, Pennsylvania 19104
}

Received for publication 10 October 1972

\begin{abstract}
Cefazolin sodium, a cephalosporin for parenteral use, was evaluated in vitro and in 26 patients. Cefazolin had activity equivalent to cephalothin against Streptococcus pneumoniae, Staphylococcus aureus, group A streptococci, and Proteus mirabilis. Cefazolin was four- to eightfold more active against Escherichia coli and slightly more active against Klebsiella pneumoniae, whereas cephalothin was slightly more active against indole-positive Proteus species. After a 500-mg dose of cefazolin intramuscularly, peak concentrations in the serum were high enough to inhibit all strains of S. pneumoniae, S. aureus, group A streptococci, $E$. coli, K. pneumoniae, and $P$. mirabilis, as well as $60 \%$ of strains of Proteus species other than $P$. mirabilis. All of 26 patients ( 18 with pneumonia, 6 with urinary tract infection, and 2 with skin infections) responded clinically and bacteriologically to cefazolin therapy. There were no major side effects of therapy, and no patient complained of pain at the site of intramuscular injection. Cefazolin is an effective cephalosporin which can be used intramuscularly for therapy of serious bacterial infections. Its major advantages over other cephalosporins are higher, more sustained concentrations in the blood and apparent lack of pain on intramuscular injection.
\end{abstract}

Cefazolin sodium, a new cephalosporin $\mathrm{C}$ antibiotic for parenteral use, is bactericidal against strains of gram-positive and gram-negative bacteria including Staphylococcus aureus, Escherichia coli, Klebsiella pneumoniae, and Proteus mirabilis. Although cefazolin sodium has a spectrum of activity similar to that of cephalothin, studies in human volunteers have indicated that it gives higher and more sustained concentrations in serum and is less irritating than cephalothin when given by intramuscular or intravenous injection (2).

The present investigation was undertaken to determine the in vitro antibacterial activity of cefazolin sodium and to evaluate it in the treatment of infections in man.

\section{MATERIALS AND METHODS}

In vitro susceptibility tests. The following strains of bacteria were isolated from patients: 32 strains of $S$. aureus, 31 strains each of $P$. mirabilis and $K$. pneumoniae, 30 strains of $E$. coli, 15 strains of Enterobacter species, 12 strains of Streplococcus pneumoniae, 8 strains of indole-positive Proteus species, and 4 strains of group A streptococci.

The susceptibility of the organisms to cefazolin sodium and cephalothin sodium was determined by a dilution method in heart infusion broth at $p H$ 7.4. The antibiotics were diluted in twofold steps in tubes containing $0.5 \mathrm{ml}$ of broth. The bacterial inoculum for each tube was $0.5 \mathrm{ml}$ of a $10^{-4}$ dilution of an 18-hr culture of each strain in heart infusion broth. Studies on $S$. pneumoniae and group A streptococci were performed in heart infusion broth with $2 \%$ sheep red blood cells. The minimal inhibitory concentration was considered to be the lowest concentration of antibiotic that prevented turbidity after $24 \mathrm{hr}$ of incubation at $37 \mathrm{C}$. At $24 \mathrm{hr}, 0.01 \mathrm{ml}$ was removed from each tube without visible growth by use of a sterile platinum loop and streaked on plates of Trypticase soy agar containing sheep red blood cells. After incubation at $37 \mathrm{C}$ for $24 \mathrm{hr}$, the plates were examined and the lowest concentration of antibiotic that resulted in no growth was taken as the minimal bactericidal concentration.

Determination of antibiotic concentrations in serum and urine. Serum and urine concentrations of cefazolin sodium were determined in patients receiving parenteral cefazolin during the third to the seventh days of therapy. Blood was obtained $0.5,1,2,4,6,8,10$, and $12 \mathrm{hr}$ after administration of a dose of cefazolin sodium. Urine specimens were obtained by having the patient void before receiving a dose of cefazolin and collecting urine voided during and at the end of the following 4-hr interval. Serum was sepa- 
rated and stored at $-20 \mathrm{C}$ until the time of assay. Urine was stored at $-20 \mathrm{C}$. The concentrations of cefazolin in serum and urine were determined by a modification of the agar diffusion method described by Wick, with the use of paper discs (3). A volume of $0.25 \mathrm{ml}$ of Bacillus subtilis spore suspension (Difco 04538-59) was mixed with 100 $\mathrm{ml}$ of melted heart infusion agar. Pour plates were made with $10 \mathrm{ml}$ for each plate and were allowed to harden. Sterile paper discs were submerged in known concentrations of cefazolin sodium freshly prepared in pooled human serum and in the sera to be tested. The discs were placed on the pour plates and incubated at $37 \mathrm{C}$ for $24 \mathrm{hr}$. Each known and unknown serum was plated in quadruplicate. A known serum was plated on each pour plate to measure uniformity of the plates. Zones of inhibition were determined with an antibiotic zone reader, and a standard curve was constructed from the known concentrations of cefazolin sodium. Concentrations of cefazolin sodium in the patients' sera were determined from this curve. Sera containing more than $15 \mu \mathrm{g} / \mathrm{ml}$ were diluted $1: 2,1: 5$, or $1: 8$ in pooled human sera for determination of the concentrations. Urine concentrations of cefazolin sodium were determined in the same manner with two exceptions: (i) the urine specimens were diluted 1:100, 1:200, 1:500, and 1:900 in heart infusion broth before the determinations were performed, and (ii) the standard curve was constructed from known concentrations of antibiotic in heart infusion broth.

Clinical studies with cefazolin sodium. Twenty-six patients were studied and treated with cefazolin sodium at the Hospital of the Medical College of Pennsylvania from December 1971 to May 1972. The criteria for inclusion in the study were the presence of bacterial infection and no previous antibiotic treatment. Specimens for bacterial cultures were obtained before therapy was started and were processed immediately.

Cefazolin was administered intramuscularly in a dosage of 1 to $3 \mathrm{~g}$ per day in divided doses every 6,8 , or $12 \mathrm{hr}$. For intramuscular injection, $1 \mathrm{~g}$ of the drug was dissolved in $2 \mathrm{ml}$ of sterile water. The following determinations were performed in patients before and after therapy: urinalysis, white blood cell count and differential, hemoglobin, hematocrit, blood urea nitrogen (BUN) serum creatinine, serum alkaline phosphatase, serum bilirubin, serum glutamic oxalacetic transaminase, serum glutamic pyruvic transaminase (SGPT), and direct and indirect Coombs' Tests.

\section{RESULTS}

In vitro antibacterial activity of cefazolin sodium and comparison with cephalothin sodium. Cefazolin sodium and cephalothin sodium had equivalent in vitro activity against S. pneumoniae, S. aureus, group A streptococei, and $P$. mirabilis. Both antibiotics inhibited all strains of $S$. pneumoniae and group A strepto- cocci at a concentration of $0.2 \mu \mathrm{g} / \mathrm{ml}$ and all strains of $S$. aureus at $0.8 \mu \mathrm{g} / \mathrm{ml}$ (Fig. 1). All $P$. mirabilis strains were inhibited by $12.5 \mu \mathrm{g}$ of cephalothin $/ \mathrm{ml}$ and $25 \mu \mathrm{g}$ of cefazolin $/ \mathrm{ml}$ (Fig. 2). Strains of $K$. pneumoniae were slightly more susceptible to cefazolin than to cephalothin (Fig. 3). All strains of $K$. pneumoniae were inhibited by $25 \mu \mathrm{g}$ of both drugs $/ \mathrm{ml}$; however, $90 \%$ of strains of $K$. pneumoniae were inhibited by $3.1 \mu \mathrm{g}$ of cefazolin $/ \mathrm{ml}$ and only $55 \%$ of strains were inhibited by the same concentration of cephalothin. Cefazolin sodium was much more active against $E$. coli than cephalothin sodium (Fig. 4). All $E$. coli strains tested were inhibited by $6.3 \mu \mathrm{g}$ of cefazolin $/ \mathrm{ml}$, whereas only $46 \%$ were inhibited by the same concentration of cephalothin. Proteus species other than $P$. mirabilis, although relatively resistant to both drugs (Fig. 5), were more susceptible to cephalothin. Most strains of Enterobacter (Fig. 6) and

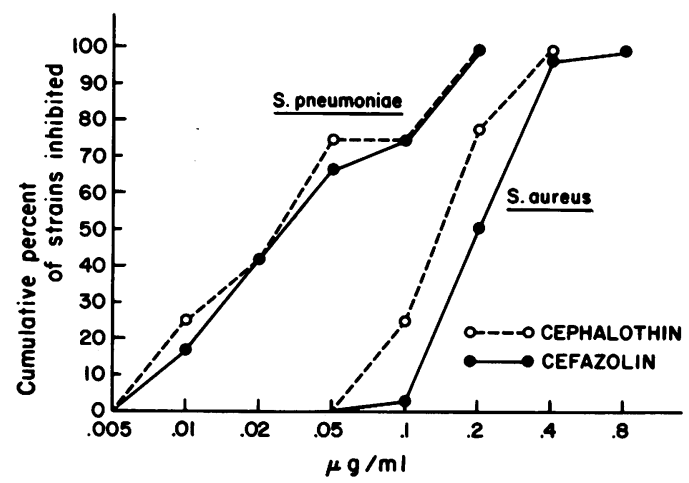

Fig. 1. Comparison of susceptibility of 12 strains of Streptococcus pneumoniae and 32 strains of Staphylococcus aureus to cefazolin and cephalothin.

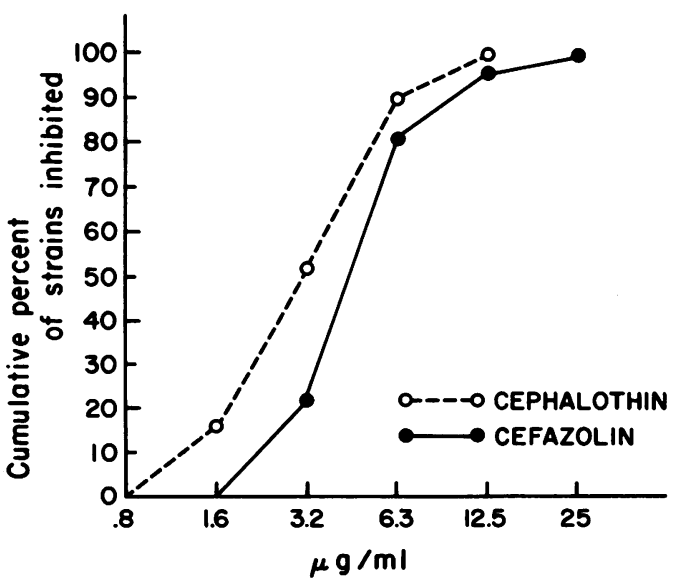

Fig. 2. Comparison of susceptibility of $\$ 1$ strains of Proteus mirabilis to cefazolin and cephalothin. 


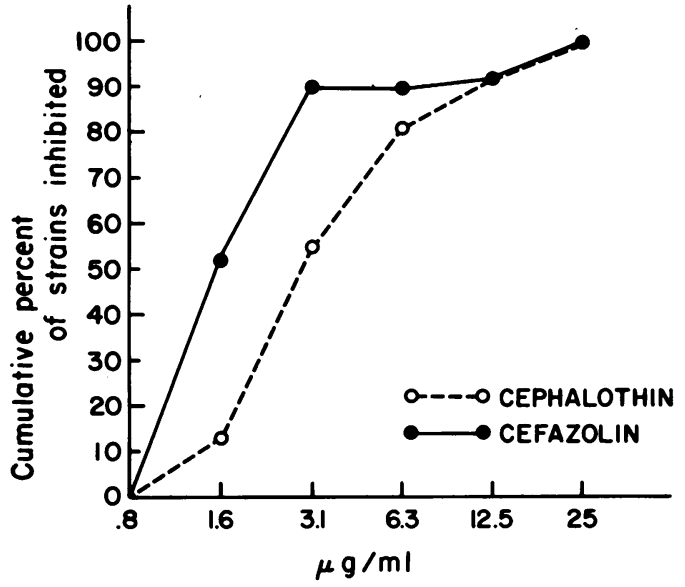

FIG. 3. Comparison of susceptibility of $\$ 1$ strains of Klebsiella pneumoniae to cefazolin and cephalothin.

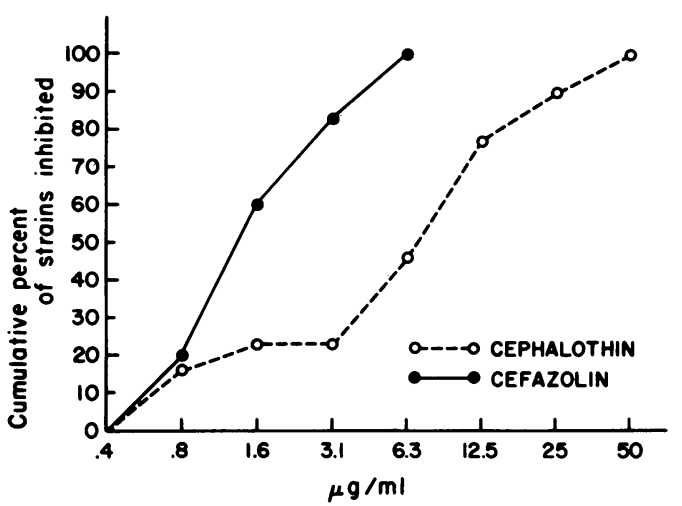

Frg. 4. Comparison of susceptibility of $\mathbf{3 0}$ strains of Escherichia coli to cefazolin and cephalothin.

all strains of Pseudomonas were resistant to $\mathbf{5 0}$ $\mu \mathrm{g}$ of cephalothin and cefazolin $/ \mathrm{ml}$. The minimal bactericidal concentrations of both antibiotics for gram-positive cocci and gram-negative bacilli were usually the same as or twice the minimal inhibitory concentrations.

Cefazolin sodium concentrations in serum and urine. As shown in Table 1, mean serum concentrations of cefazolin after a $500-\mathrm{mg}$ intramuscular dose in patients with normal serum creatinine concentration were $34.4 \mu \mathrm{g} / \mathrm{ml}(20.5$ to $47 \mu \mathrm{g} / \mathrm{ml})$ at $0.5 \mathrm{hr}, 36.4 \mu \mathrm{g} / \mathrm{ml}(17.8$ to 56 $\mu \mathrm{g} / \mathrm{ml})$ at $1 \mathrm{hr}, 25.6 \mu \mathrm{g} / \mathrm{ml}(16.5$ to $45 \mu \mathrm{g} / \mathrm{ml})$ at $2 \mathrm{hr}$, and $16.1 \mu \mathrm{g} / \mathrm{ml}(8.8$ to $21 \mu \mathrm{g} / \mathrm{ml})$ at 4 $\mathrm{hr}$. In two patients, levels of drug were still measurable in the serum at $12 \mathrm{hr}$. In patients with abnormal renal function (serum creatinine greater than $1.2 \mathrm{mg} / 100 \mathrm{ml}$ ), the serum concentrations of cefazolin were more sustained.
During the $4 \mathrm{hr}$ after administration of $\mathbf{5 0 0}$ mg of cefazolin intramuscularly, concentrations in the urine ranged from 380 to $3,600 \mu \mathrm{g} / \mathrm{ml}$. During this 4-hr collection, approximately 43 to $81 \%$ of injected cefazolin activity was recovered in the urine in patients with normal renal function, and 22 to $43 \%$ of the injected activity was recovered in patients with abnormal renal function (excluding one patient who received a 1-g dose).

Clinical studies with cefazolin sodium. The clinical data are summarized in Table 2. The ages of the 26 patients ranged from 30 to 88 years with a mean of 60 years, and 18 of them were males.

Patients with pneumonia. In 14 of the 18 patients with pneumonia, the infecting organism was S. pneumoniae (patients 1-14). Response to therapy was prompt in the 14 patients, and all

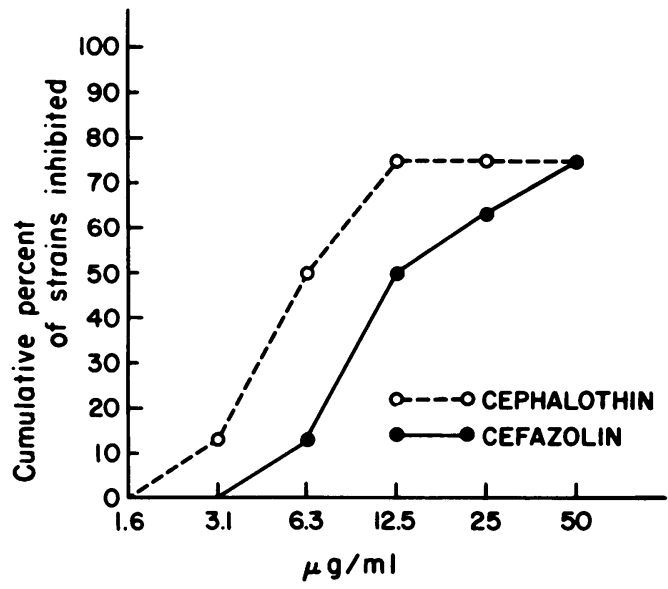

Fig. 5. Comparison of susceptibility of eight strains of indole-positive Proteus species to cefazolin and cephalothin.

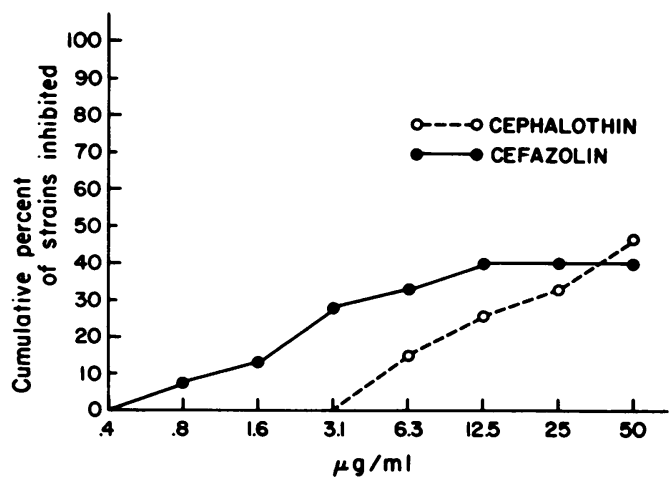

Fig. 6. Comparison of susceptibility of 15 strains of Enterobacter to cefazolin and cephalothin. 
TABLE 1. Concentrations of cefazolin sodium in serum and urine of 18 patients after injection of $500 \mathrm{mg}$ intramuscularly

\begin{tabular}{|c|c|c|c|c|c|c|c|c|c|c|c|c|}
\hline \multirow{2}{*}{ Patient $^{a}$} & \multirow{2}{*}{$\begin{array}{c}\text { Creati- } \\
\text { nine }(\mathrm{mg} / \\
100 \mathrm{ml})\end{array}$} & \multicolumn{8}{|c|}{ Concn in serum $(\mu \mathrm{g} / \mathrm{ml})$ at indicated $\mathrm{hr}$} & \multirow{2}{*}{$\begin{array}{l}\text { Concn } \\
\text { in urine } \\
(\mu \mathrm{g} / \mathrm{ml})\end{array}$} & \multirow{2}{*}{$\begin{array}{l}\text { Drug in 4-hr } \\
\text { collection } \\
\text { (mg) }\end{array}$} & \multirow{2}{*}{$\begin{array}{c}\begin{array}{c}\text { Drug } \\
\text { excreted } \\
(\%)\end{array} \\
(\%)\end{array}$} \\
\hline & & 0.5 & 1 & 2 & 4 & 6 & 8 & 10 & 12 & & & \\
\hline 1 & 0.9 & 35.5 & 43.5 & 25.7 & 80.0 & & & & & 3,600 & 216 & 43.2 \\
\hline 2 & 0.9 & 40.5 & 56.0 & 45.0 & 20.5 & & & & & & & \\
\hline 3 & 0.9 & 37.0 & 17.8 & 16.5 & 13.8 & & & & & & & \\
\hline 4 & 0.9 & 20.5 & 21.0 & 16.5 & 12.5 & & & & & 1,700 & 299 & 59.8 \\
\hline 5 & 1.1 & 47.0 & 43.0 & 25.5 & 19.0 & 6.9 & 4.2 & 2.7 & 2.7 & 1,600 & 406 & 81.2 \\
\hline 6 & 1.1 & 26.0 & 37.0 & 24.5 & 21.0 & & & & & & & \\
\hline 7 & 1.1 & & & & & & & 3.8 & 3.5 & & & \\
\hline 8 & 0.9 & & & & 8.8 & 3.8 & 2.0 & & & 380 & 317 & 63.4 \\
\hline Mean & & 34.4 & 36.4 & 25.6 & 16.1 & & & & & & & \\
\hline 9 & 1.7 & 32.0 & 31.5 & 32.0 & 27.0 & & & & & 2,200 & & \\
\hline 10 & 1.6 & - & 34.0 & 32.0 & 21.5 & & & & & 810 & 214 & 42.8 \\
\hline 11 & 1.6 & 20.5 & 24.5 & 35.0 & 25.0 & & & & & & & \\
\hline 12 & 2.9 & 88.0 & 97.6 & 104.0 & 68.0 & & & & & 1,050 & 164 & 32.8 \\
\hline 13 & 1.4 & 38.0 & & & 35.0 & 29.0 & 22.0 & & 18.4 & 560 & 193 & 38.6 \\
\hline 14 & 1.4 & & & & & & 14.0 & 5.8 & 3.7 & 860 & 112 & 22.4 \\
\hline 15 & 2.2 & & & & & 9.2 & 4.9 & & 6.3 & & & \\
\hline 16 & 1.3 & & & & & 43.0 & 32.0 & & 10.0 & & & \\
\hline Mean & & 44.6 & 46.9 & 50.8 & 35.3 & & & & & & & \\
\hline $17^{b}$ & 1.6 & 17.5 & 16.5 & 80.0 & 72.0 & 50.0 & 45.0 & & & 1,700 & 612 & 61.2 \\
\hline
\end{tabular}

a Patients 1-8 had normal serum creatinine concentrations, and patients 9-17 had abnormal serum creatinine concentrations.

b Dose of $1 \mathrm{~g}$ administered intramuscularly.

were cured. One died of cardiac causes on the day therapy was stopped. Two patients had pneumonia caused by anaerobic streptococci, one diagnosed by transtracheal aspiration and one diagnosed by percutaneous needle aspiration of the lung. One of these two patients (no. 15) responded slowly and received cefazolin for a total of 22 days. The second patient responded rapidly and received the drug for only 7 days. The causative organisms isolated by transtracheal aspiration in the other two patients (no. 17 and 18) were Haemophilus parainfluenzae and $H$. influenzae. They responded rapidly to cefazolin therapy.

Patients with urinary tract infection. Six patients had urinary tract infection, and five of these had symptoms of pyelonephritis (i.e., fever and flank pain). Two patients (no. 20 and 22) had bacteremia. All responded to cefazolin. $\mathrm{Pa}$ tients 23 and 24 were cured (i.e., no bacteriuria 1 month after discontinuing cefazolin). Three patients relapsed after therapy; patient 20 had a relapse of both bacteriuria and bacteremia, and no. 21 and 22 had a relapse of bacteriuria alone. Patient 20 was retreated with cefazolin for another 14 days during which a transurethral resection for prostatic hypertrophy was performed. After the cefazolin was discontinued the second time, he was treated with cephalexin for 2 weeks and was then lost to follow-up with sterile urine cultures. During cefazolin therapy, patient 19, who was critically ill, developed bacteremia caused by an Enterobacter strain resistant to $\mathbf{5 0}$ $\mu \mathrm{g}$ of cefazolin $/ \mathrm{ml}$.

Patients with miscellaneous infections. Two patients had infections caused by group $\mathbf{A}$ streptococci; patient 25 had cellulitis of the leg and patient 26 had multiple abscesses secondary to "skin popping" of heroin. Both patients responded well to cefazolin therapy.

Side effects of therapy. Patient 25 developed drug fever which rapidly disappeared after therapy was discontinued. Patients 7, 10, 13 , and 15 developed eosinophilia of 3 to $5 \%$. There were no rashes.

Patients 6 and 17 had decreases in hematocrit from 40 and $42 \%$ to 34 and $35 \%$ respectively during hydration. These decreases in hematocrit were not thought to be related to administration of cefazolin.

Patient 19 had a rise in BUN from 15 to 37 $\mathrm{mg} / 100 \mathrm{ml}$ after bacteremia and a respiratory arrest associated with hypotension. At the same time, the SGPT changed from 59 to 250 milliunits $/ \mathrm{ml}$ and the alkaline phosphatase rose from 231 to 450 milliunits $/ \mathrm{ml}$. Two other patients had 


\begin{tabular}{|c|c|c|c|c|c|c|c|c|c|c|c|c|c|c|c|}
\hline $\begin{array}{l}\text { 蒙 } \\
\text { 苟 }\end{array}$ & 总 & 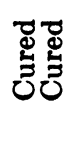 & D & ర్లై & 己. & 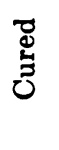 & D & ర్d & 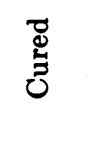 & ర્屯 & 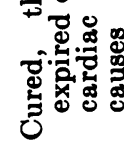 & 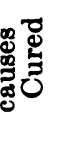 & 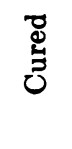 & 总 & 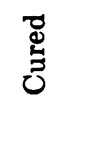 \\
\hline 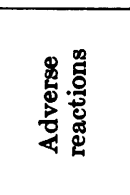 & 忘 & 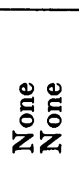 & 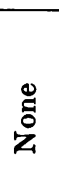 & $\begin{array}{l}0 \\
\mathbf{z}\end{array}$ & . & 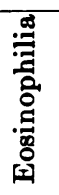 & $\begin{array}{l}0 \\
\text { Z } \\
\text { z }\end{array}$ & 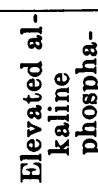 & 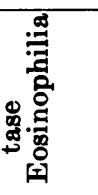 & : & ๕̈ & 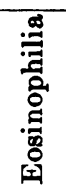 & 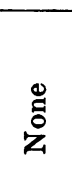 & 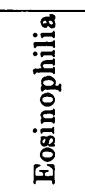 & $\stackrel{0}{0}$ \\
\hline 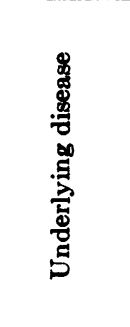 & 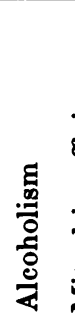 & 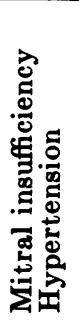 & 号 & $\begin{array}{l}\frac{\Xi}{0} \\
\frac{0}{0} \\
\frac{\pi}{0} \\
\frac{e}{4}\end{array}$ & 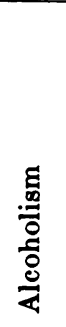 & 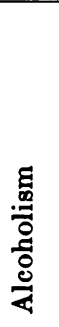 & 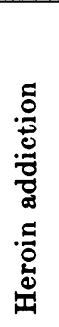 & $\stackrel{0}{Z}$ & 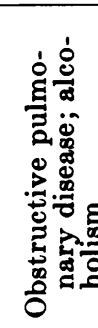 & 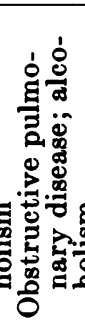 & 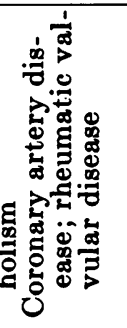 & 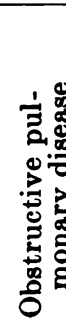 & 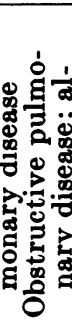 & : & $\begin{array}{l}\frac{0}{2} \\
\frac{0}{0} \\
\frac{0}{0} \\
\frac{0}{4}\end{array}$ \\
\hline 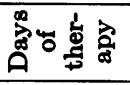 & $N$ & $\infty \infty$ & $\infty$ & $N$ & $N$ & $\sim$ & $\sim$ & $\sim$ & 0 & 0 & 0 & $\infty$ & 0 & ม & $\sim$ \\
\hline 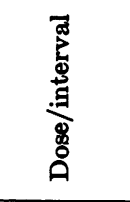 & $\begin{array}{l}5 \\
5 \\
0 \\
0 \\
\text { a } \\
8 \\
8\end{array}$ & 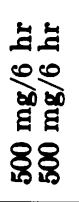 & $\begin{array}{l}\frac{5}{9} \\
0 \\
80 \\
\Xi \\
8 \\
8\end{array}$ & $\begin{array}{l}\frac{a}{2} \\
0 \\
0 \\
8 \\
8 \\
8 \\
8\end{array}$ & $\begin{array}{l}\text { s. } \\
0 \\
0 \\
\text { â } \\
8 \\
8\end{array}$ & $\begin{array}{l}\text { s. } \\
0 \\
0 \\
\text { घี } \\
8 \\
8\end{array}$ & 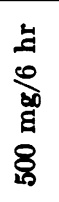 & 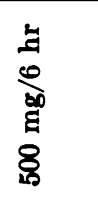 & 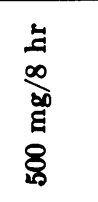 & 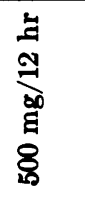 & $\begin{array}{l}\stackrel{2}{a} \\
0 \\
0 \\
\text { है } \\
8 \\
8\end{array}$ & $\begin{array}{l}\frac{2}{2} \\
0 \\
0 \\
8 \\
8 \\
8 \\
0\end{array}$ & $\begin{array}{l}5 \\
5 \\
0 \\
00 \\
8 \\
8 \\
8\end{array}$ & 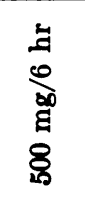 & $\begin{array}{l}5 \\
\infty \\
\infty \\
-1\end{array}$ \\
\hline 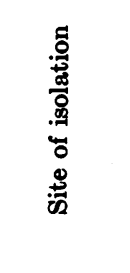 & 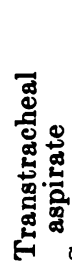 & 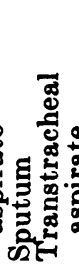 & 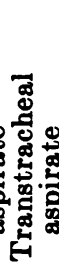 & 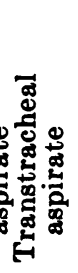 & 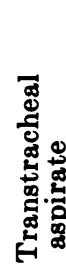 & 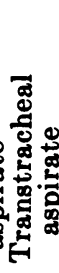 & 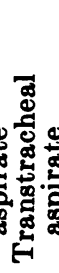 & 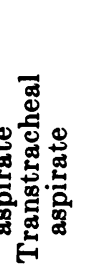 & 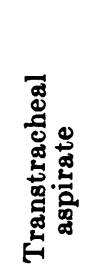 & 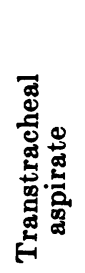 & 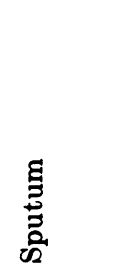 & 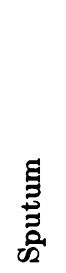 & 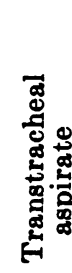 & 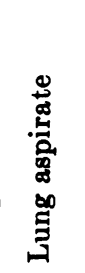 & 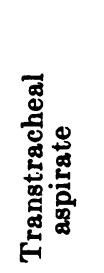 \\
\hline 㺼 & 1 & 11 & $\begin{array}{l}\overrightarrow{0} \\
0\end{array}$ & [D & D2 & $\pi 2$ & §̊ & $\stackrel{\overrightarrow{0}}{0}$ & ö & 苛 & 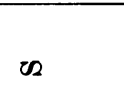 & $\overrightarrow{0}$ & ণ̣ & $\ddot{0}$ & $\Omega$ \\
\hline 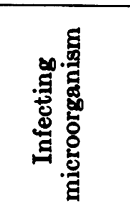 & 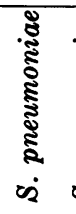 & 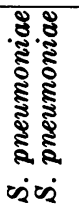 & 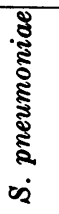 & 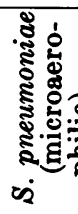 & 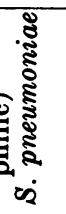 & 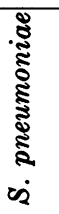 & 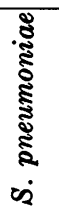 & 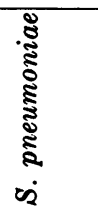 & 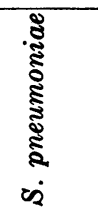 & 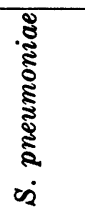 & 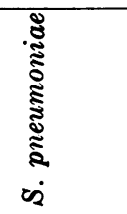 & 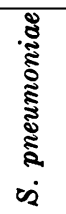 & 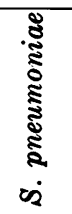 & \multicolumn{2}{|c|}{ 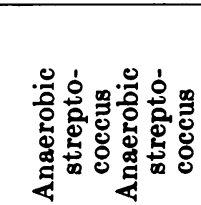 } \\
\hline 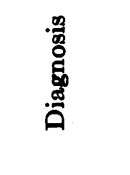 & 离 & 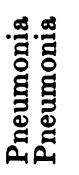 & 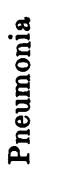 & 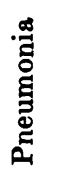 & 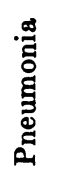 & 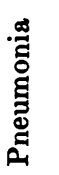 & 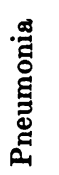 & 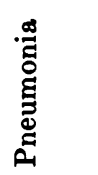 & 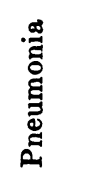 & 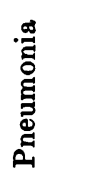 & 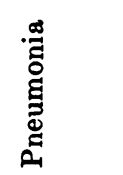 & 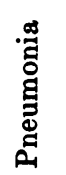 & . & 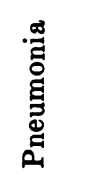 & 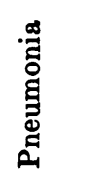 \\
\hline 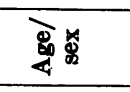 & 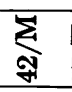 & $\sum_{i=8}$ & 8 & \& & 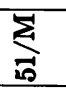 & $\sum_{\substack{\delta \\
\delta}}$ & 造 & $\sum_{8}$ & 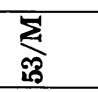 & 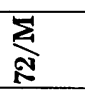 & 点 & $\stackrel{\sum}{R}$ & 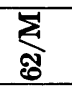 & $\sum_{i n d}$ & $\sum_{0}^{\Sigma}$ \\
\hline के & - & œ & 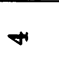 & 20 & 0 & $n$ & $\infty$ & $\sigma$ & 응 & $\Rightarrow$ & $\stackrel{乛}{7}$ & $\stackrel{9}{\rightarrow}$ & 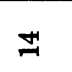 & $\stackrel{2}{2}$ & $\stackrel{\mathscr{2}}{2}$ \\
\hline
\end{tabular}




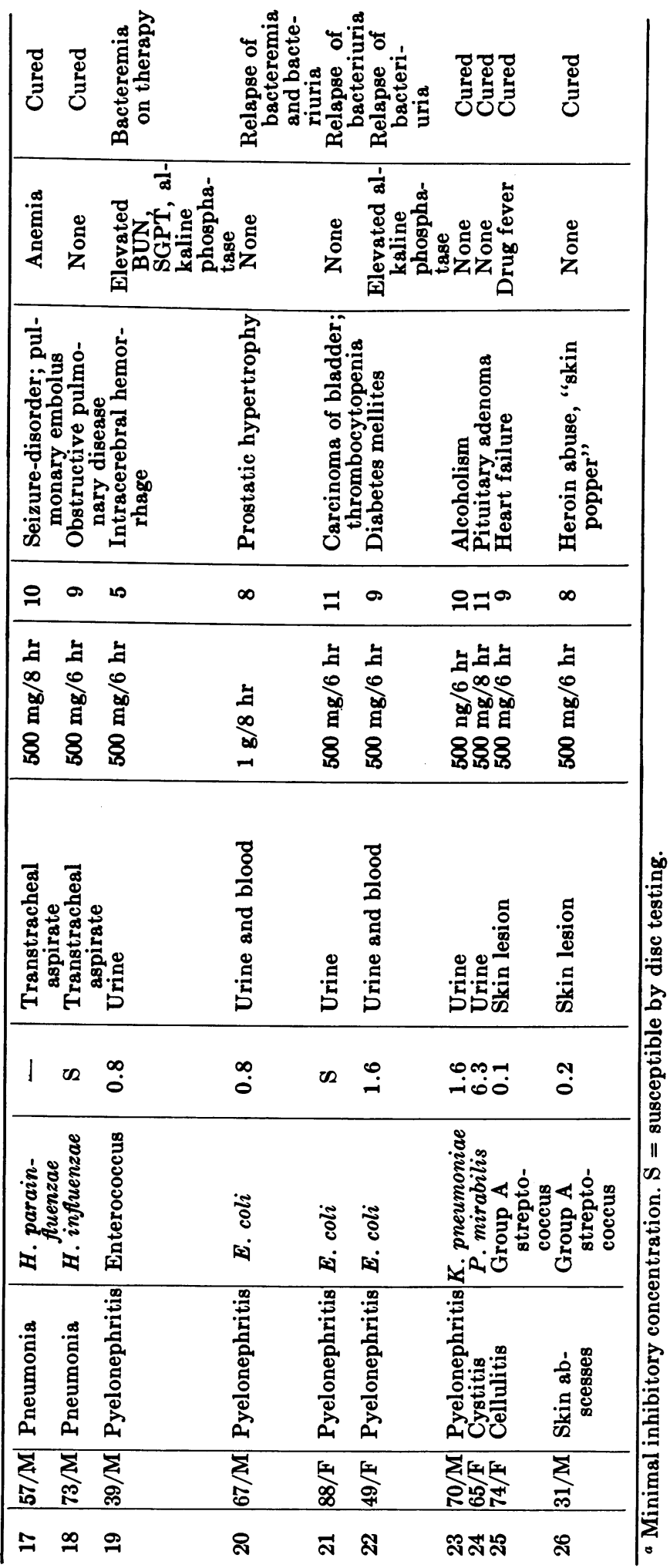


changes in alkaline phosphatase from 74 to 93 microunits/ml (no. 9) and 55 to 100 microunits/ml (no. 22) during therapy. The cause of the elevations of alkaline phosphatase is not known.

All other laboratory tests which were previously normal were not altered by therapy. No patient complained of pain at the site of intramuscular injection.

\section{DISCUSSION}

Cefazolin and cephalothin seem to be equivalent drugs with respect to antibacterial activity against gram-positive cocci. Cefazolin is fourto eight-fold more active than cephalothin against $E$. coli and slightly more active against $K$. pneumoniae, whereas cephalothin is slightly more active against Proteus sp. other than $P$. mirabilis and is equivalent in activity against $P$. mirabilis. The major advantages of cefazolin over cephalothin would seem to be that of higher, more sustained concentrations in serum and the lack of pain after intramuscular injection.

The present investigation has demonstrated that cefazolin reaches high concentrations in the blood and urine after parenteral administration. The mean serum concentration $1 \mathrm{hr}$ after intramuscular injection of $500 \mathrm{mg}$ of cefazolin was $36.4 \mu \mathrm{g} / \mathrm{ml}$ in patients with normal renal function (serum creatinine, $1.1 \mathrm{mg} / 100 \mathrm{ml}$ or less). Four hours after intramuscular injection of 500 $\mathrm{mg}$ of cefazolin, the mean serum concentration was $16.1 \mu \mathrm{g} / \mathrm{ml}$. This compares with a mean peak concentration of about $8 \mu \mathrm{g} / \mathrm{ml}$ at $0.5 \mathrm{hr}$ and about $1 \mu \mathrm{g} / \mathrm{ml}$ at $4 \mathrm{hr}$ after intramuscular injection of $500 \mathrm{mg}$ of cephalothin (1). There were still measurable levels of cefazolin present $12 \mathrm{hr}$ after injection. With cephalothin, there were no measurable serum levels after $6 \mathrm{hr}$. The peak serum concentrations of cefazolin were high enough to inhibit all strains of $S$. pneumoniae, S. aureus, group A streptococci, E. coli, $K$. pneumoniae, and $P$. mirabilis, as well as $60 \%$ of strains of Proteus species other than $P$. mirabilis. All strains of $E$. coli, $P$. mirabilis, and
K. pneumoniae were inhibited by concentrations obtained in the urine.

In this study, all of the 26 patients responded clinically and bacteriologically to cefazolin therapy. The relapses which occurred in three of six patients with urinary tract infection were probably related more to the nature of the patients than to failure of therapy. One of these patients had carcinoma of the urinary bladder and another had prostatic hypertrophy, both of which caused obstructive uropathy.

The eosinophilia observed in 4 of the 26 patients was probably related to cefazolin. The elevation of BUN in one patient was thought to be due to hypotension following a respiratory arrest. This patient also had a rise in alkaline phosphatase and SGPT, also probably related to hypotension. Two other patients had unexplained rises in alkaline phosphatase. The drop in hematocrit in two patients was probably caused by hydration. The most bothersome side effect was drug fever in one patient which promptly disappeared at the end of therapy.

From these studies, it can be concluded that cefazolin is an effective cephalosporin which can be used intramuscularly for therapy of serious bacterial infections. It results in higher and more sustained blood levels than cephalothin and has the advantage of being well tolerated intramuscularly.

\section{ACKNOWLEDGMENTS}

The technical assistance of Kathleen King, Jerry Rosenzweig, and Marianna Wakulowska is gratefully acknowledged.

This study was supported in part by Smith Kline \& French Laboratories.

\section{LITERATURE CITED}

1. Griffith, R. S., and H. R. Black. 1971. Blood, urine and tissue concentrations of the cephalosporin antibiotics in normal subjects. Postgrad. Med. J. (Feb. Suppl.) 47:32-40.

2. Ishiyama, S., I. Nakayama, H. Iwamoto, S. Iwai, M. Okui, and T. Matsubara. 1971. Absorption, tissue concentration, and organ distribution of cefazolin. Antimicrob. Ag. Chemother. 1970, p. 476-480.

3. Wick, W. E., and W. S. Boniece. 1965. In vitro and in vivo laboratory evaluation of cephaloglycin and cephaloridine. Appl. Microbiol. 13:248-253. 